\title{
Reading and Viewing Sex in Early Modern French Vernacular Medicine
}

SARAH E. PARKER

Jacksonville University

\begin{abstract}
Discussions of sex in early modern medical discourse did not simply legitimize a titillating topic. Medicine was engaged in a broader struggle to establish itself as a legitimate and professionally defined discipline; yet many practitioners marketed their ideas to a non-professional public readership. Using both textual and visual material, this article analyzes the tension between these aims in two sixteenth-century French vernacular works that discussed medical topics related to sex: La Dissection des parties du corps humain (1546) by Charles Estienne and the Erreurs Populaires (first edition, 1578) by Laurent Joubert. These medical authors employed visual and textual strategies to legitimize sexual content and to increase their professional reputations - while nevertheless exploiting the erotic nature of the content in order to improve the marketability of their publications.
\end{abstract}

Le traitement du sexe dans le discours médical des débuts de la modernité ne cherchait pas seulement à légitimer un thème émoustillant. La médecine était aussi engagée dans un débat plus important visant à établir son statut en tant que discipline professionnelle légitime et bien définie. Toutefois, plusieurs praticiens de la discipline destinaient leurs travaux à un public non professionnel. À travers des documents à la fois écrits et visuels, cet article analyse les tensions entre ces objectifs dans deux ouvrages du seizième siècle de langue française se penchant sur des questions en lien avec le sexe: La Dissection des parties du corps humain (1546) de Charles Estienne et Erreurs Populaires (1578) de Laurent Joubert. Ces auteurs en médecine on utilisé des stratégies visuelles et textuelles afin de légitimer létude du sexe et de promouvoir leur réputation professionnelle, et ce, tout en tablant sur la nature érotique de ces thèmes afin d’augmenter l'intérêt du marché pour leurs publications.

Tn the fifth and sixth chapters of François Rabelais's Pantagruel (ca. 1532), the titular hero considers what he might study at university. ${ }^{1}$ He tours all of the major universities of France, forming his opinions about them with a perspicacity that mocks the hypocrisy of higher learning. At a certain point he finds himself at the university in Montpellier, Rabelais's own alma mater for medical school and one of the best medical universities in sixteenth-century

1. I am grateful to the Huntington Library and to the University of Warwick's Reading Publics workshop and research fellowship, funded by the Mellon Foundation, for research assistance on this article. I would also like to thank Amyrose McCue Gill, Vanessa McCarthy, and the anonymous reviewers for feedback on drafts of this article.

Renaissance and Reformation / Renaissance et Réforme 38.4, Fall / automne 2015 
Europe. Pantagruel assesses the possibility of studying medicine in this famous locale with an amusing list of pros and cons: "Puis vint à Montpellier où il trouva fort bons vins de Mirevaulx et joyeuse compagnie, et se cuida mettre à étudier en Médecine: mais il considéra que l'état fâcheux par trop mélancholique, et que les médecins sentaient les clystères comme vieux diables." 2 Pantagruel's admiration of physicians as a bon vivant crowd that enjoys good wine and good company is tempered by his concern that they may relish a bit too much the professional obligation to administer enemas. This description, though clearly exaggerated for comic effect, illustrates concerns about the early modern physician's proximity to the private and eroticized regions of the body. The physician had a legitimate, professional reason, for example, to penetrate the anus of his patient with a clyster that would, according to the Galenic model of humoral medicine, purge that patient of the dangerous humours that could compromise his or her health. Passages such as this one from Rabelais, though, indicate skepticism on the part of the general public about the purely professional motivation of these physicians. Rabelais's mocking representation of doctors as lecherous "old devils" sits uncomfortably with claims that sixteenth-century learned physicians were making about the august nature of their profession in order to distinguish themselves from other groups of medical practitioners.

Rabelais's text is one of an array of Renaissance cultural documents that mocks the potentially disconcerting intimacy of physicians with their patients. The humorous effect of Machiavelli's popular comedy La Mandragola (1524), for example, depends on the joke that doctors had privileged access to the bodies of sexually active women. The main character, Callimaco, needs to come up with a plan that will help him sleep with the beautiful wife of Nicia, an old fool just asking to be cuckolded, so he poses as a doctor who claims to have a cure for the couple's lack of a male heir. Callimaco's position as a physician allows him a physical intimacy with the otherwise off-limits woman as well as

\footnotetext{
2. François Rabelais, Les Cinq Livres, ed. Jean Céard et al. (Paris: La Pochothèque, 1995), 325. "He went then to Montpellier, where he met with the good wines of Mirevaux, and good jovial company withal, and thought to have set himself to the study of physic; but he considered that that calling was too troublesome and melancholic, and that physicians did smell of glisters [sic] like old devils." The English translation is from François Rabelais, The first [second] book of the works of Mr. Francis Rabelais, Doctor in Physick, trans. Thomas Urquhart (London: Richard Baddeley, 1653), 27; accessed 3 September 2013, through Early English Books Online, http://eebo.chadwyck.com/home.
} 
the right to speak frankly with the concerned husband about sex. ${ }^{3}$ Similarly, the Dutch painter Jan Steen (ca. 1626-79) was known for a series of paintings thematizing the "Doctor's Visit" (1663-65), and many of these works depict the doctor with a flirtatious or even lecherous expression as he enjoys physical proximity to an attractive female patient. ${ }^{4}$

Rabelais's story, Machiavelli's comedy, and Steen's art were meant as entertainment, but they dramatize a very real tension for early modern learned physicians. In the sixteenth century, university-educated physicians were in the process of defining and claiming a professional legitimacy that they hoped would distinguish them from the medical practitioners they considered inferior in skill and learning: empirics and "wise women," as well as surgeons or apothecaries educated in their trade but inclined to offer medical advice that many learned physicians perceived as encroaching on their territory. ${ }^{5}$ Physicians' attempts to widen their authority included moving towards a professional identity that contrasted with the image of the indecorous doctor. This did not, however, stop many learned physicians from venturing into the world of vernacular printing and publishing on topics relating to early modern sex acts. The overarching early modern medical term for anything related to sex,

3. Tessa Gurney discusses the moral ambivalence about doctors and the practice of medicine in the context of La Mandragola in her thesis, “'A me non venderà egli vesciche': Questionable Medici and Medicine Questioned in Machiavelli's Mandragola” (Master's thesis, University of North Carolina, 2011), accessed 15 September 2013, https://cdr.lib.unc.edu/indexablecontent?id=uuid:e28c6da8-7ec7-41748534-1e77b78011c5\&ds=DATA_FILE. For more general discussions of physicians' access to women, see Margaret Pelling, "Compromised by Gender: The Role of the Male Medical Practitioner in Early Modern England," in The Task of Healing: Medicine, Religion and Gender in England and the Netherlands, 1450-1800, ed. Hilary Marland and Margaret Pelling (Rotterdam: Erasmus Publishing, 1996), 101-33; Liane McTavish, Childbirth and the Display of Authority in Early Modern France (Burlington, VT: Ashgate, 2005); Michael Stolberg, "Examining the Body, c. 1500-1750," in The Routledge History of Sex and the Body (Routledge: New York, 2013), 91-105; and Cathy McClive, Menstruation and Procreation in Early Modern France (Burlington, VT: Ashgate, 2015).

4. On the relationship between Dutch art and medicine, see Laurinda Dixon, Perilous Chastity: Women and Illness in Pre-Enlightenment Art and Medicine (Ithaca, NY: Cornell University Press, 1995). On Steen, see Sutton et al., Masters of Seventeenth-Century Dutch Genre Painting (Philadelphia: Philadelphia Museum of Art, 1984).

5. See L. W. B. Brockliss and Colin Jones, The Medical World of Early Modern France (Oxford: Clarendon Press, 1997), 11. The process of professionalization began earlier in Italy. See Nancy Siraisi, Medieval and Early Renaissance Medicine: An Introduction to Knowledge and Practice (Chicago: Chicago University Press, 1990). 
reproduction, and gestation was "generation," and physicians began to publish works on this topic in the vernacular because they hoped to treat the diseases of women who could afford the services of a physician, even though decorum had previously dictated that women should be treated by midwives. Claiming that male practitioners could treat diseases of women that affected the womb, breast, and other private areas of women's bodies risked breaching these rules of decorum and perpetuating the image of the lecherous doctor. As we will see, physician-authors attempted to counter this risk by developing a strong professional persona in their published works.

As Andrea Carlino and Michel Jeanneret have recently illustrated, in the sixteenth century learned physicians began to publish in the vernacular in order to reach an audience that was literate, but not fluent, in Latin, which had previously been the only language of learned medicine. ${ }^{7}$ Physicians began to target a more localized readership of potential patients rather than an international audience of medical colleagues and learned (mostly) men interested in the philosophical concerns of medicine. ${ }^{8}$ This new audience included aristocratic women, nobles who had some Latin education but were more comfortable in the vernacular, and the burgeoning market of book buyers from the middle classes. By writing in the vernacular, the physician-author was making a decision to write to an audience outside of his professional community. Publishing in the vernacular was accompanied by a set of risks for the medical professional, including the concern that topics related to sex and generation, perfectly acceptable in Latin texts targeting only trained doctors, might be inappropriate for a broader audience.

As Sarah Toulalan argues in her book Imagining Sex: Pornography and Bodies in Seventeenth-Century England, while many modern critics have attempted to define pornography according to the intent of its creator, it is impossible to recuperate authorial intent with any degree of certainty. ${ }^{9}$ We can,

6. Lauren Kassell, "Medical Understandings of the Body, c. 1500-1750," in The Routledge History of Sex and the Body (Routledge: New York, 2013), 57.

7. Vulgariser la médecine, ed. Andrea Carlino and Michel Jeanneret (Geneva: Droz, 2009), addresses medical publication in French and Italian from 1550 to 1650.

8. Ian Maclean provides an overview of Latin medical publishing in this period in his essay "The Diffusion of Learned Medicine in the Sixteenth Century through the Printed Book," in Learning and the Marketplace: Essays in the History of the Early Modern Book (Leiden: Brill, 2009), 59-86.

9. Sarah Toulalan, Imagining Sex: Pornography and Bodies in Seventeenth-Century England (Oxford: Oxford University Press, 2007), 4. 
however, say with a certain amount of confidence that publishers aimed to sell books for profit and that medical authors publishing in the vernacular hoped to achieve wide name recognition to increase their reputations. The inclusion of verbal and visual material relating to generation risked a breach of professional decorum even as it provided a potential boost to these publications' marketability.

Works on generation in the vernacular were clearly popular in sixteenthcentury France. Most of these works, however, were not by university-trained physicians but rather by surgeons, midwives, apothecaries, and even laymen. ${ }^{10}$ As Liane McTavish points out, many of these publications placed rhetorical emphasis on the work's contribution to the spread of knowledge, but in fact they mostly conformed to generic conventions and primarily were "involved in producing the reputation of their authors." ${ }^{\prime 1}$ The proliferation of treatises on topics related to generation and the fact that many of these works went through multiple editions suggest that material related to sex acts sold well. Such works would have been in demand because they contained practical information related to childbirth, women's health, and the production of male heirs. Additionally, though, the titillating images and descriptions of sex-acts couched in the legitimizing context of the medical treatise would only have increased such works' marketability.

While most publications on generation seem to have been uncontroversial, the surgeon Ambroise Paré created a stir when he published his Oeuvres in 1575. Though the primary group attacking Parés work was the Paris medical faculty, it was also criticized by a certain Galoppe, who represented the Prévot des marchands and the échevins (provost of merchants and magistrates) on the grounds

10. The definitive work on French vernacular obstetrical treatises is Valerie Worth-Stylianou's Les Traités D’obstétrique en Langue Française au Seuil de la Modernité (Geneva: Droz, 2007). McTavish's Childbirth and the Display of Authority in Early Modern France documents the increasing number of such treatises by male surgeons. One of the most famous midwifery texts was the Rosegarten, written by a German apothecary and translated into French twice in the sixteenth century. See Monica Green, "The Sources of Eucharius Rösslin's 'Rosegarden for Pregnant Women and Midwives' (1513)," Medical History 53 (2009): 167-92. Alison Klairmont Lingo's “Print's Role in the Politics of Women's Health Care in Early Modern France," in Culture and Identity in Early Modern Europe (1500-1800): Essays in Honor of Natalie Zemon Davis, ed. Barbara D. Diefendorf and Carla Hesse (Ann Arbor, MI: University of Michigan Press, 1993), 203-21, discusses a pamphlet by a layman that warns women against the services of midwives (212).

11. McTavish, 25. 
that the book was an affront to decorum. ${ }^{12}$ This accusation stemmed from Parés explicit discussions of topics related to the sex acts leading to generation as well as controversial topics such as abortion. As Valerie Worth-Stylianou points out, however, two years earlier this material had appeared almost word-for-word in a work devoted to the topic of generation without generating controversy. This suggests that Paré was more likely censored for the hubris implied in printing a "complete works" despite the fact that he had no university training. The College of Physicians sought to censor the work of a successful surgeon who published extensively in the vernacular because he risked encroaching on their professional territory, further proof of McTavish's argument that medical publication was primarily concerned with promoting authorial reputation.

The learned physician's decision to publish on topics related to generation in the vernacular was therefore fraught with concerns about reputation, marketability, audience, and decorum. The two physician-authors I wish to discuss for the remainder of this essay made the relatively unusual decision to publish in this field despite such complications. These works are Charles Estienne's $\mathrm{La}$ Dissection des parties du corps humain (1546) and Laurent Joubert's Erreurs Populaires (1578), and they represent two examples of the contradictory pulls that the early modern book market placed on learned physicians at a moment when they were engaged in attempts to solidify their professional status. On the one hand, medical publications in the vernacular tended to make explicit arguments about the superiority of learned medicine over other, competing approaches to medical care. Yet this legitimizing, "ambassadorial" function of vernacular medical publication was also paired with the kind of content and presentation that would help a book to sell in the competitive early modern book market. The inclusion of titillating content in the already-popular genre of vernacular medicine ${ }^{13}$ may have made these works even more desirable to a

12. Valerie Worth-Stylianou, "The Definition of Obscene Material 1570-1615: Three Medical Treatises Held to Account," in Early Modern French Studies 14: Obscenity, ed. Hugh Roberts, et al. (Charlottesville, VA: Rockwood Press, 2010), 148-67.

13. Andrew Pettegree discusses the varieties of audiences for medical works, including works in the vernacular, in his chapter "Healing," in The Book in the Renaissance (New Haven: Yale University Press, 2011), but he does not discuss the potentially erotic content of such literature in relation to early modern book buyers. Though scholars frequently gesture towards the appeal of the potentially titillating content of medical works like Joubert's, much work remains to be done on the possibility that readers may have purchased medical texts specifically for their erotic material and the possibility that some 
variety of consumers. Vernacular medical works like Estienne's were primarily targeted at a professional audience of practitioners who were not educated at early modern universities, especially barber-surgeons and midwives. Such works also would have been purchased, though, by readers literate in the vernacular, such as aristocratic men and women and members of the merchant class, and Joubert's work specifically targeted this latter group as an audience of potential patients. These physician-authors aimed to bring reproductive sex acts into the realm of legitimate concern for learned physicians while also profiting from the marketability of sexually explicit content.

\section{Estienne: representing sex in the vernacular anatomical treatise}

Charles Estienne's La dissection des parties du corps humain (1546) represents a relatively early example of a learned physician publishing in the vernacular. This book is a translation into the vernacular of a Latin edition published a year earlier, in 1545. ${ }^{14}$ The Latin work would have served as an anatomical textbook for university medical students, and in this context the treatise presents itself as an entirely legitimate and learned work. Yet with the vernacular edition, Estienne and his publishers were likely targeting an audience of barbersurgeons, midwives, and anyone else literate in the vernacular and wealthy enough to afford this costly folio. ${ }^{15}$ In addition to extensive textual discussions of anatomical dissection and study, both the Latin and the vernacular editions feature an impressive series of sixty-four full-page woodcuts as well as many

physicians were catering to this potential market. For discussions of early modern erotic writing, see Lynn Hunt, ed., The Invention of Pornography: Obscenity and the Origins of Modernity, 1500-1800 (New York: Zone Books, 1993); Ian Moulton, Before Pornography: Erotic Writing in Early Modern England (Oxford: Oxford University Press, 2000); Joan DeJean, The Reinvention of Obscenity: Sex, Lies, and Tabloids in Early Modern France (Chicago: Chicago University Press, 2002); and Hugh Roberts, et al., ed., Obscénités renaissantes (Geneva: Droz, 2011).

14. Estienne had begun working on the treatise much earlier in the 1530s in collaboration with the surgeon Etienne de la Rivière. The two had a legal disagreement, and the publication of the work was delayed, eventually appearing in 1545 in Latin followed by the French translation in 1546. On the chronology of this conflict and the work's eventual publication, see K. B. Roberts and J. D. W. Tomlinson, The Fabric of the Body: European Traditions of Anatomical Illustrations (Oxford: Clarendon Press, 1992). 15. Pierre Huard and Mirko Drazen Grmek give the most extensive history of the book's context in their introduction to L'oeuvre de Charles Estienne et l'école anatomique parisienne (Paris: Cercle du Livre Précieux, 1965), which also contains reproductions of La Dissection's illustrations. 
smaller illustrations of human anatomy. Similar to other early modern anatomical treatises, the work follows the step-by-step process of dissecting a male body, discussing its anatomical features in the text, and representing them visually in images. However, the book also includes a series of ten images of the female body intended to illustrate the aspects of women's bodies that are not covered by the general exposition of human (male) anatomy in the main text. As Bette Talvacchia has shown, nine of the ten female figures, which are all concerned with female reproductive anatomy, ${ }^{16}$ derive from a series of erotic prints that had become popular in Italy and France. Estienne's printer uses a series of drawings by Perino del Vaga and Rosso Fiorentino that were then engraved by Italian artist Jacopo Caraglio as part of the series Gli amori degli dei (The Loves of the Gods, ca. 1526). ${ }^{17}$ Estienne worked with Etienne de la Rivière, an accomplished surgeon, to create the portions of these illustrations that represented dissection, which were superimposed onto the figures from The Loves of the Gods. While I do not wish to suggest that images of male figures could not be erotic, in Estienne's work the female figures are decidedly more eroticized than the male figures. Unlike the "muscle men" of Andreas Vesalius's groundbreaking anatomical treatise De humani corporis fabrica (1543), with their elegant contrapposto stance and beautifully sculpted musculature, Estienne's male figures are awkward and oddly positioned, standing in noticeable contrast to the eroticized female figures in the final section of the book.

The erotic content of the ten plates representing female anatomy sits uneasily with the convincingly learned context for the production and marketing of La Dissection. Estienne, as a learned physician with close ties to Simon de Colines's publishing house in Paris, provides a particularly fascinating example of the learned doctor's relationship to the publishing market. Coming from a family of publishers, Estienne would have been in a position to know a great deal about publishing, including how to produce books that would be marketable to early modern audiences. Estienne's printer, Colines, had taken over

16. Bette Talvacchia, Taking Positions: On the Erotic in Renaissance Culture (Princeton, NJ: Princeton University Press, 1999), 164.

17. Talvacchia, 127, 164. She also argues that Giulio Romano, the artist behind the images accompanying Aretino's erotic sonnets in I modi, may have contributed to the drawing of at least some of these original figures (127-33). 
the prestigious humanist printing house of Estienne's father, Henri Estienne, ${ }^{18}$ when the latter died and Colines married his widow. Later, Charles Estienne's brother, Robert Estienne, took over the Estienne publishing house, and Simon de Colines went on to set up his own house. ${ }^{19}$

In choosing Simon de Colines as his printer, Estienne associated his work with a house that published primarily learned works in Latin, including Latin translations of ancient Greek medical texts. Colines was even the libraire juré, the official printer for the University of Paris, meaning that Colines would have supplied textbooks to the university, including medical books for students training to become physicians. ${ }^{20}$ The book's paratexts advertise this learned context to the interested reader. On the title page, Estienne's name is followed by "docteur en medicine" to indicate his status as a university-educated physician. The title page also features a privilège de roi, the closest thing that early modern printers had to copyright, which evidenced institutional endorsement at the highest secular level.

In her analysis of these images, Talvacchia argues that the medical and artistic contexts of the treatise and the accompanying illustrations were meant to be harmonious, and indeed the sixteenth century was not characterized by a

18. This is Henri Estienne the elder. His grandson, Henri Estienne the younger, took over the family printing house from Charles's brother Robert and was an important printer in the mid-sixteenth century. 19. It is unclear why Charles chose to publish with Colines rather than with his brother's printing house. Harvey Cushing proposes that this was because Robert had begun publishing less prestigious books, $A$ Bio-Bibliography of Andreas Vesalius (Hamden, CT: Archon Books, 1962), 35. If we accept this argument, it strengthens the claim that Estienne was interested in emphasizing the learned nature of his treatise, which would help to legitimize the inclusion of erotic prints representing female reproductive anatomy. Kay Amert, on the other hand, has argued that Simon de Colines and Robert Estienne had a relationship more of collaboration than competition. See "Intertwining Strengths: Simon de Colines and Robert Estienne," Book History 8 (2005): 1-10, as well as her study of Colines: The Scythe and the Rabbit: Simon de Colines and the Culture of the Book in Renaissance Paris, ed. Robert Bringhurst (Rochester, NY: RIT Press, 2012).

20. Amert, 1. La Dissection also benefitted from the artistry of woodcutters Jean Jollat and Geoffroy Tory, who had worked on learned treatises in Latin in addition to works in the vernacular that were part of the humanist effort to elevate the French language to the level of Latin by publishing learned texts in French. The seminal early modern treatise on this topic is Joachim du Bellay, La Deffence et illustration de la langue Françoyse (1549) (Geneva: Droz, 2001). The criticism on this intellectual movement towards the vernacular is vast. See the recent work of Hassan Melehy, The Poetics of Literary Transfer in Early Modern France and England (Burlington, VT: Ashgate, 2010). 
strict disciplinary split between, for example, art and medicine.${ }^{21}$ Acknowledging the intimate link between art and medicine, especially in the field of anatomy, however, does not necessarily mean that we should simply ignore the erotic content of these images, especially given early modern concerns about male physicians' access to female bodies. The association between sex acts and the anatomy of the female body is especially strong in the ninth of Estienne's series of ten images representing the entirety of the womb. This woodcut (Figure 1) features a woman who appears to be in the throes of an orgasm. Reclining on a sumptuous bed with her head tossed back and her eyes closed, she has reached her left hand over her head. Rather than covering her face in shame, she allows the viewer to see that she is lost in a moment of sexual pleasure. She grips her own hair while her right hand drapes over the pillows and blankets at the base of the bed with the fingers curling as they caress the fabrics adorning this opulent boudoir. These gestures suggest that the figure is lost in the intensity of a deep sexual pleasure, evident even to her outermost limbs as she presses her right foot into the floor and curls her left toes, which are propped up for us to notice on the trunk in the foreground. The sources for this female figure further highlight the erotic implications of the image. The figure taken from The Loves of the Gods series is remarkably similar to Guilio Bonasone's image of Danaës moment of impregnation by Jupiter's golden rain and to Caraglio's Jupiter and Antiope after Perino del Vaga. ${ }^{22}$ Though some details are different, there is a decided homology of the figures' gestures, the placement of the feet, and even the drapery over the beds, proving that Estienne's choice for representing female anatomy drew on an erotic reference that would have been fairly well known due to the popularity of the Loves of the Gods series.

21. Talvacchia, 163. Works on the relationship between art and anatomy in the Renaissance include: A. Hyatt Mayor, Artists and Anatomists (New York: Metropolitan Museum of Art, 1984); Diane R. Karp, Ars medica: Art, Medicine, and the Human Condition (Philadelphia: University of Pennsylvania Press, 1985); Bernard Schultz, Art and Anatomy in Renaissance Italy (Ann Arbor: University of Michigan Press, 1985); Roberts and Tomlinson, The Fabric of the Body; Domenico Laurenza, Art and Anatomy in Renaissance Italy: Images from a Scientific Revolution (New York: Metropolitan Museum of Art, 2012).

22. Paula Findlen's article "Humanism, Politics and Pornography in Renaissance Italy," in The Invention of Pornography: Obscenity and the Origins of Modernity, 1500-1800, ed. Lynn Hunt (New York: Zone Books, 1993), 49-108, describes the Bonasone in terms of the titillating response that such works provoked among early modern viewers (64). Talvacchia's book shows the links between this woodcut and the Caraglio (176 ff). 
The anatomical use of this image goes even further than the erotic voyeurism of the print series. The female figure has been separated from her partner (whether the figure of Jupiter himself in the Caraglio or the more abstract golden rain in the Bonasone). The lover is replaced with the invisible anatomist and the book's viewer, who penetrate the feminine body through dissection. The anatomist's role merges with the role of the lover who has just made this woman orgasm, something early moderns considered necessary for a woman to conceive. ${ }^{23}$ The image's references to reproduction through the revelation of the womb combined with the representation of the woman's orgasm disturbingly link the penetrative work of the physician and anatomist with the sexual act. $^{24}$

Estienne included this erotic imagery in the first Latin edition of his anatomical treatise, which was published a year before the vernacular edition was released. The original Latin version of the work contained the same woodcuts, which would have seemed more in keeping with decorum because the audience was limited to a professional class of learned men. Estienne and Colines were both interested in the marketability of the published work, and they decided to proceed with the production of a vernacular translation that included these images despite the fact that it would reach an entirely different kind of audience. While it is true that the cost of carving new blocks for less titillating plates would have been very high, it is nonetheless significant that Estienne

23. This has become common knowledge among early modern scholars and has been most extensively discussed in Thomas Laqueur's, Making Sex: Body and Gender from the Greeks to Freud (Harvard University Press: 1990), 38-45. Laqueur's notion of the one-sex model has been dismissed by most historians, see Helen King's recent study The One-Sex Body on Trial: The Classical and Early Modern Evidence (Burlington, VT: Ashgate, 2013); the idea, however, that both the woman and the man needed to orgasm in order to conceive was a basic tenet of the two-seed model that Hippocrates proposed in On Seed, and that Galen, Rhazes, and Avicenna also supported in their writings. According to this theory of generation, both male and female contributed seed in the formation of offspring. Significantly, Avicenna cites this fact as a justification for the physician's right to "teach about sexual pleasure" in The Canon of Medicine, book 3, fen 20, tr. 1, chapter 44, cited in Same-Sex Desire in the English Renaissance: A Sourcebook of Texts: 1470-1650, ed. Kenneth Borris (New York: Routledge, 2004), 130.

24. On eroticizing the anatomist's act of penetration, see Dominique Brancher, "Anatomiste Pornographe: Narration obscene et figuration de soi dans la literature médicale renaissante," in Early Modern French Studies 14: Obscenity, 168-94. On the desire to reveal the secret inner organs of the female body, see Katharine Park, Secrets of Women: Gender, Generation, and the Origins of Human Dissection (New York: Zone Books, 2006). 
and Colines saw an opportunity for profit in a translation that included these woodcuts, given that a work in the vernacular would have reached a broader audience. $^{25}$

As Patricia Simons has convincingly shown, the definition of obscenity emerges from the reaction of an audience to a work. ${ }^{26}$ Accordingly, aside from occasional anecdotal evidence, much of our understanding about how early moderns perceived potentially erotic material is gleaned from the censorship records of the Catholic Church, which targeted printed material for its disconcerting accessibility. While an erotic painting could be enjoyed by a few based on the discretion of the patron, an engraving or a book in the vernacular introduced the possibility of wide consumption. ${ }^{27}$ Yet despite its reproducibility, Estienne's work does not appear to have met with such censorship from either the Catholic Church or the Faculty of Medicine in Paris, a body that did occasionally oppose the dissemination of professional medical content in the vernacular. As we shall see, this made Estienne more successful at distributing erotic material in a vernacular work than Joubert would prove to be. ${ }^{28}$ This was at least in part due to the different cultural climate of the mid-sixteenth century when the church did not have the influence that it would later exert on the book trade in the years following the decrees of the Council of Trent (1545-63). Additionally, the vernacular version of $L a$ Dissection maintained its professional appearance as a textbook emerging from a specifically learned context of production. Joubert's work, though in some ways less sensational than Estienne's, would meet greater resistance because it targeted a broader audience and was

25. The 1645 and 1646 editions were the only major editions of this work, and they both included the full set of anatomical illustrations.

26. Patricia Simons, "Gender, Sight, and Scandal in Renaissance France," in Obscénités renaissantes, ed. Hugh Roberts, et al. (Geneva: Droz, 2011), 115-28.

27. Findlen gives the example of Titian's erotic paintings in the Escorial of Philip II. These were hidden behind a curtain and shown only to visitors he personally selected. This kind of audience contrasts with the widespread availability of something like Aretino's postures, a series of erotic woodcuts accompanied by raunchy sonnets. The censors responded much more harshly to the latter kind of erotica while the former mostly passed under the radar. See Findlen, 54.

28. Joubert was not censored by the Faculty of Medicine, it is important to keep in mind, but by his colleagues. The Faculty usually focused on medical work in the vernacular that was published by unlearned competitors, as was the case with the complete works of barber-surgeon Ambroise Paré, discussed above. 
published in an environment that was increasingly influenced by attempts at censorship from both the church and the faculty of medicine.

\section{Joubert: sex acts and female readership}

Estienne seems to have maintained the professional focus of his work by publishing with a printer who supplied textbooks to the University of Paris and by maintaining the overall presentation of the earlier Latin version. Joubert's treatise on popular errors, the Erreurs Populaires (1578), on the other hand, exemplifies the difficult road that learned physicians had to navigate if they deliberately sought a more popular audience for their publications. Joubert, who served as chancellor of the Montpellier medical faculty from $1566^{29}$ and who became médecin ordinaire du roi (Royal Physician to Henry III) in 1579, was unquestionably a learned physician. Near the end of his life when he had accumulated many years of experience, he saw the need to share this experience with a wider audience of non-professional readers educated in the vernacular. Erreurs Populaires describes the numerous "popular errors" in belief and practice perpetuated by common people untrained in the art of medicine. The book's conversational style offers a compendium of such erroneous beliefs and the reasons that they are false in order to encourage a broad readership to seek treatment from learned physicians. While Joubert's work contains information intended to change popular beliefs, he does not encourage his readership to use this knowledge on themselves or others. Instead, he repeatedly insists that this copia of errors only proves the unquestionable superiority of learned practitioners such as himself. This claim serves both to promote his reputation and to denigrate the medical practices of competitors, especially midwives and apothecaries.

After the Erreurs Populaires was published, however, it met with criticism regarding the problem of representing material on sex and generation, especially when targeting a readership that included literate women. Included in the edition were instructions about how to discern whether or not a woman was a virgin, the concern that a woman's vagina could poison the man she was sleeping with, and the relative merits of breastfeeding. Joubert's desire to discuss

29. Montpellier was widely regarded as one of the best medical schools in Europe. The most thorough history of the medical school at Montpellier is by Louis Dulieu, La Médecine à Montpellier du XII au XXe siècle (Paris: Hervas, 1990). On Montpellier's relationship to early modern medicine more broadly, see Siraisi, Medieval and Early Renaissance Medicine. 
material relating to early modern sex acts and their effect on people's (and especially women's) health risked breaching the very decorum that learned physicians relied on in order to justify categorizing topics relating to generation as a legitimate part of their professional domain.

There is evidence that Joubert and his publisher were aware of the marketability of a work that focused on potentially titillating topics, even though they might be seen as inappropriate for an audience literate in the vernacular. First, he chose to publish the first edition with Simon Millanges in Bordeaux, a printer who specialized in vernacular works with a focus on historical and religious topics, and who was also famous for publishing the first two editions of Michel de Montaigne's remarkably successful Essais. The fact that Millanges agreed to publish Joubert's work indicates that he expected that it would sell well in the early modern book market.

Second, Joubert also anticipates criticisms from his fellow physicians in the prefatory material to the 1578 first edition of the Erreurs Populaires. His preface to the royal dedicatee, the princess of France and queen of Navarre Marguerite de Valois, adopts a tone of self-defence to justify the publication of such a work in the vernacular. As he acknowledged, doctors were not typically supposed to share with the general public the kind of information that he included in this vernacular work, which focuses almost exclusively on the topics of sex and generation:

Voyla un mal tres-dangereus duquel les medecins en sont cause, pour avoir trop divulgué \& communiqué leurs regles, \& ordonnances, que le vulgaire prand cruëmant, \& ne sçait disposer bien à propos. C'est donc aux medecins de remedier à ce mal.

Here we have a very dangerous problem of which doctors are the cause, for having revealed and shared their rules and prescriptions, such that the common people understand these things crudely and do not understand how to prepare them correctly. It is thus up to doctors to remedy this damage. $^{30}$

30. Laurent Joubert, Erreurs Populaires au fait de la medicine et regime de regime de santé (Bordeaux: S. Millanges, 1578), n.p. Bayerische Staats Bibliothek. Joubert translations are my own. Citations will be from this edition unless otherwise stated. 
The quotation implies that it would have been better for doctors never to have shared information about their profession and their remedies with any kind of public audience. ${ }^{31}$ This unprofessional divulgence has, however, already happened, so it is up to doctors to remedy the effects caused by their colleagues' negligence. The treatise thus aims to shore up the position of the learned physician, but it approaches this goal in a way that mirrors the very affronts to learned medicine that such physicians perceived in the proliferation of vernacular treatises. ${ }^{32}$

The implications here are complex. Joubert suggests that he writes the book almost against his will, because he sees a need among patients who have been misinformed or who have misinterpreted accurate information. As a good doctor, it is his job to remedy the ills of the body, including those that are brought about when the average person attempts to self-diagnose and self-treat or consults an unqualified practitioner. Joubert's self-defence assures the reader that his primary focus in the work is inextricably bound to his identity as a learned physician seeking to defend his profession and protect his potential patients from the dangers of unlearned medicine. In other words, Joubert takes on the role of learned physician for his readers, enacting the textual therapeutics of a doctor remedying the ills that plague the minds of his audience of "patients" and endanger their health.

Third, Joubert's long term plan for Erreurs Populaires, which was never finished, indicates that he prioritized the portions of the work that focused on sex acts and generation. The book was meant to be a six-part project that focused more broadly on the "regimen" that features in the full title (Erreurs populaires au fait de la medicine et regime de santé, or Popular Errors on the Topic of Medicine and Health Regimen). Yet the first edition does not give a great deal of

31. Joubert's referent here is unclear, though it is interesting that this work appears only three years after the controversial Oeuvres of Ambroise Paré published in 1575. That Joubert would be insulting Paré here is unlikely, though, as he describes Paré in highly complimentary terms in his first chapter on pregnancy: "maitre Ambroise Paré, premier chirurgien du Roi, tres docte, curieus, diligent \& liberal à publier les talans de grand savoir \& experience que Dieu lui ha commis" (233-34). ("Master Ambroise Paré, first surgeon to the king, most learned, curious, diligent, and generous in publishing the talents of great knowledge and experience that God has granted him.”)

32. Joubert was not alone in engaging in this kind of paradox. As Aginieszka Steczowicz illustrates in her essay "Paradoxe et antiparadoxe dans la littérature médicale Lyonnaise: Barthélémy Aneau critique de Pierre Tolet," in Vulgariser la médécine, the physician Aneau wrote in the vernacular to defend learned (Latin) medicine against a vernacular attack on its value as a discipline. 
information about regimen, a main feature of sixteenth-century learned medicine. Instead, the edition contains only the first part of Joubert's six-part project, the part that discusses popular errors relating to generation. Regimen was fundamental to early modern medicine's reliance on humoral theory, a concept central to the Galenic model of medicine and health. While one's pre-existing humoral condition - the tendency to have a particular humour predominate over the others-was a given fact of one's complexion, the health of the body could be manipulated by adjusting what were known as the "non-naturals," these being air, drinking and eating, work (or exercise and rest), sleeping and waking, excretion and retention, and the passions or perturbations of the soul. ${ }^{33}$ This work of maintaining the optimum complexion, or humoral balance, was achieved by monitoring the effects of the non-naturals on the body. The topics related to the maintenance of the non-naturals, the regimen that would maintain health, make up parts 2, 3, and 4 of Joubert's plan for the six-part project. The smaller print on the title page and the table of contents reveals that the book's first edition, printed and sold in 1578, contains only the first of these six planned parts. ${ }^{34}$ This first book focuses on popular ideas about conception, pregnancy, childbirth, and the nursing of infants. In other words, the work that Joubert chooses to write and publish first out of the six he had planned contains the material that would have been the most likely to appear indecorous and even erotic to the broad and non-professional audience that was purchasing books in the vernacular.

It seems likely that Joubert and his publisher began with the material focusing on sex acts and topics related to generation in order to capture the attention of their buyers and perhaps increase sales of this first instalment of a larger project. Furthermore, the material related to generation, pregnancy, childbirth, and nursing pertains almost exclusively to women's health and to women's bodies and suggests a target audience that includes women. ${ }^{35}$ While Joubert might

33. In the words of Siraisi: "The physician was supposed to maintain health by regulating the non-naturals, that is, by tailoring the patient's diet, exercise, rest, environmental conditions, and psychological well-being so as to maintain him or her with the optimum complexion" (121).

34. Joubert gives a detailed overview of what each book will contain, complete with chapter headings and sub-headings for each of the topics that he plans to discuss. Books 2 through 4 will focus on the particulars of the "regime de santé" that the title page announces, but these are not included in the initial publication of the Erreurs Populaires, which consists only of the first book.

35. Joubert would also have been writing for unlearned practitioners, especially barber-surgeons. While a learned physician may well have read a vernacular work like this one, the Erreurs Populaires was not 
have avoided hostile critical reception by addressing his work to midwives or male practitioners rather than an audience of literate women (as exemplified by his dedicatee), instead he comes across as hostile to midwives and he addresses the average layperson rather than an audience with any knowledge of medicine. As a physician, Joubert hopes to correct the tendency among highborn women to seek out the help of midwives as opposed to learned physicians during pregnancy and birth, and his decision to name Marguerite de Valois as his dedicatee signals that his target audience included women. ${ }^{36}$

By including women in his audience, Joubert seeks to advance his reputation as a good doctor and to encourage aristocratic potential patients to seek treatment from learned physicians like himself. He runs into difficulty in targeting this nonprofessional audience of women, though, because he includes content that many early moderns worried would offend decorum, especially in an audience that included the more imperfect sex ${ }^{37}$ At one point in the 1578 edition of the Erreurs Populaires, for example, Joubert explains that whores ("putains") give birth more easily because their "parties honteuses sont si usees,

targeted at such. Joubert explicitly states in his prologue that he is writing for a general audience of patients who might make dangerous medical mistakes due to their misunderstandings about medicine. Medical works targeted at an audience of learned peers, by contrast, were written exclusively in Latin. See Maclean, "The Diffusion of Learned Medicine in the Sixteenth Century through the Printed Book" (note 8 , above).

36. Joubert writes to Marguerite, "Aussi la recompense an sera beaucoup plus glorieuse, quand vous aurez de vostre jugement \& autorité condamné les Erreurs populaires, an faisant que la vie des hommes soit desormais plus assure," n.p. ("Your recompense will be even more glorious once you have made use of your judgment and authority to condemn popular errors, guaranteeing from this point on the life [health] of all men.") On the subject of midwives, Joubert writes in disugust: "Loutrecuidance \& presompcion d'aucunes fames est telle, quelles panset s'antandre mieus a touttes maladies peculieres des fames [...] que les plus suffisans medecins du monde," 347. ("The arrogance and presumption of some women is such that they think they understand all of the maladies particular to women better than the most competent physicians in the world.") On midwives in this period, see Brockliss and Jones, 262-73. See also Hilary Marland, ed., The Art of Midwifery: Early Modern Midwives in Europe (New York: Routledge, 1993); Wendy Perkins, Midwifery and Medicine in Early Modern France: Louise Bourgeois (Exeter: University of Exeter Press, 1996); McTavish, Childbirth and the Display of Authority in Early Modern France.

37. Michael Stolberg's "Examining the Body, c. 1500-1750," in The Routledge History of Sex and the Body (New York: Routledge, 2013), 91-105, offers nuanced insight into the role of shame and the importance of decorum and notions of "decency" in female-patient to male-physician interactions in the early modern period. 
que le passage bien frayé, est aisé a l'anfant." ${ }^{38}$ This vivid description of the vaginal state of prostitutes could hardly have been considered acceptable reading for the educated women of polite society who would have made up part of Joubert's audience for such material. In insisting that the male physician has an important and necessary place in the process of giving birth, which had hitherto been managed by women, Joubert argues that learned physicians should be granted intimate access to the bodies of sexually active women. Yet he does so in the context of a vernacular treatise on popular errors that covered taboo topics. In choosing this particular context, Joubert risks reinforcing the stereotype of the licentious physician just as he is hoping to convince his readership that learned physicians should treat women patients.

Joubert attempts to mitigate this problem by calling attention to his professional expertise. In his preface to the dedicatee, Marguerite de Valois, he points out that he has practised medicine for twenty-five years, and that his entire life has been devoted to two projects: teaching young people the science of medicine and eradicating the false opinions and errors that plague medicine, surgery, and apothecaryship. In the Erreurs Populaires, he combines his passion for teaching with his passion for clearing away erroneous thought. His work aims to instruct an audience that extends beyond learned university medical students in order to reach practitioners uneducated in Latin as well as a much broader lay audience of people whose lives are affected by a false understanding of health and the body. Joubert's confident attitude toward his project continues in his letter to the reader in the 1578 edition, "Au Lectuer d'esprit libre et studieus" ("To the open-minded and studious reader"). ${ }^{39}$ Here he asserts his authority on the subject matter by emphasizing that he has gathered popular sayings and beliefs from a variety of people in a host of countries and collected the most thorough catalogue that he could from this personal knowledge. The letter to the reader, furthermore, comes directly after the extensive proposed table of contents for the entire Erreurs Populaires (of which, as mentioned above, this publication represented only the first part of six). In arranging the paratextual material of the book in this way, Joubert is careful to position himself as a figure

38. Joubert, 335. Their "shameful parts are so used that the passageway that has been well opened up is easy for the child [to pass through]."

39. There are no page numbers in this part of the edition, but the "Au Lecteur" letter is about fifty pages into the work and immediately follows the detailed table of contents that Joubert provides for the entire proposed Erreurs Populaires. 
of professional authority, showing the reader the extent of his knowledge before he informs her or him of his qualifications to speak on this matter.

Joubert's attempt to combine his roles as teacher and as doctor seems to backfire, though. While insisting on his professional authority, Joubert goes on to create an intimate link with his audience of readers, inviting them to join him in the composition of this encyclopedic text: "[Je] t'inviter, ô Lecteur desprit libre \& studieus, a manvoyer des propos samblables a ceus-cy." ${ }^{40} \mathrm{By}$ emphasizing his readers' mental virtues, the "open-minded and studious" adjectives repeated in the title of the address and here again only a few lines into the content of that letter, Joubert pulls his reader into the project of textual creation that leads to knowledge formation. He is treating the reader not as a patient in need of a doctor's expertise, but as a respected student who also has something to contribute to the process of learning. In other words, Joubert is treating his reader rather like he would have treated his own young medical students, the men at Montpellier who studied medicine under his tutelage.

The intimate relationship that Joubert sought to develop with his readers and his decision to dedicate the entire work to an important aristocratic woman created a scandal upon the publication of his work. While not much is known about the precise nature of the attacks that were launched against Joubert and his work, there is ample evidence in subsequent editions of the Erreurs Populaires that Joubert and his supporters responded to negative critical reception of the first edition of the book. The second edition, printed in 1579, included a note from Joubert's Bordeaux publisher, Simon Millanges, warning the reader that some words may seem "un peu obscenes" and stating that he has placed an asterisk next to the especially worrisome chapters on proofs of virginity, so that the reader can decide whether or not she or he wants to skip that part of the text. ${ }^{41}$

40. Joubert, n.p. "[I]" invite you, O open-minded and studious reader, to send me sayings similar to these here." From the first page of the letter to the reader.

41. Erreurs Populaires au fait de la medecine et regime de santé (Bordeaux: S. Millanges, 1579), 56. As Worth-Stylianou and DeJean point out, this is one of the first appearances of the term "obscène" in French. Worth-Stylianou gives a detailed account of the response to the Erreurs Populaires in "The Definition of Obscene Material," 148-67. Aside from the treatise "Contredicts aux erreurs populeres" by the physician Dominique Reulin, we do not have textual evidence of the attack on Joubert, but only the defensive maneuvers Joubert and his publisher make in responding to attacks. On the fact that this early, 
In the self-defence that he added to the 1579 edition, Joubert recounts a fascinating anecdote that illustrates the difference between his persona as a medical professor teaching his students and his authorial role as a learned physician tending his patients. He defends, in particular, his occasional use in his anatomy lectures of jovial language that might be perceived as bawdy:

je me fuis abstenu de tous mots propres aux parties honteuses [...] comme aussi ils ne furet onc prononcez de ma langue: ja-soit qu'és anatomies publiques, je m'egaye assez libremant, a traiter joyeusemant de ces parties là, ainsi que le sujet m'invite. Mais je prans an tesmoins, mille \& mille de mes auditeurs an divers tams, medecins, chirurgiens, \& apoticaires, qui sont épars en divers androis de l'Europe, si'ils m'ont ouy jamais proferer un mot proper aus dittes parties, où à l'acte venerien.

[In this work] I have absolutely refrained from all words naming the shameful parts, and in addition these words have never once left my tongue: although at public anatomies I enjoy myself pretty well in referring humorously to these parts, insofar as the subject invites me to. But I call as witness the thousands and thousands of my auditors at various times, doctors, surgeons, and apothecaries, who are scattered in many locations around Europe, if they ever heard me use a word specific to these shameful parts or to the venereal act. ${ }^{42}$

This passage illustrates the complex contradictions involved in Joubert's selfpresentation as author and physician. He insists that while writing his treatise he has been nothing but circumspect in choosing the words to describe the potentially offensive topics of sex and the sexual organs. He underscores this point by going a step further to claim that he has never even let such offensive language escape his mouth, a hyperbole that aims to underscore that as a physician he values the decorum demanded of his profession. It is highly unlikely that a frank and outspoken doctor like Joubert, the author of a treatise on laughter and a figure at Montpellier where medical students and professors

\footnotetext{
"uncensored" edition was nevertheless still used as the basis for later editions, see Worth-Stylianou, Les Traités d’obstétrique, 227-33.
}

42. "Lauteur a ses amis et biendisans," 1579 edition. 
often wrote and acted in farcical theatre productions, would be able to claim that he had never even uttered an indecorous word in reference to those private parts serving generation. ${ }^{43}$ Indeed, in the following sentence he concedes that at public dissections he has made use of bawdy humour in reference to the exposed body that would have been on the table before him. The difference between a scenario such as an oral lecture at a public dissection for medical practitioners and a work printed in the vernacular and targeted, at least in part, at a female audience, drew the attention of Joubert's critics at a time when it was not always clear what vernacular words for human genitalia were appropriate for learned discussion and which would come across as obscene. ${ }^{44}$ While the teacherly relationship that Joubert has with his students or with the local surgeons and apothecaries who attend his dissection lectures may permit the use of the frank language and humour in discussing the sexual organs and the sexual act itself, the world of vernacular medical printing does not easily allow this liberty. ${ }^{45}$

Joubert's defense illustrates the difficulty of combining the pedagogic role of medical educator trying to reach an audience beyond the Latin reading medical student or colleague with the therapeutic role of the physician healing a patient. Joubert aims to adapt his role as teacher to a broader audience of people who suffer the consequences of mistaken beliefs. This goal sits uncomfortably, though, with the doctor-patient relationship that also governs the treatise. While the teacher presents information as clearly and frankly as

43. Joubert was the author of a treatise on laughter, the Traité du ris (Paris: Nicolas Chesneau, 1579). On this work, see Gregory de Rocher, Rabelais' Laughers and Joubert's Traité du Ris (Birmingham, AL: University of Alabama Press, 1979). On the Montpellier medical farce, see Felix Platter's mention of farces when he was studying at the Montpellier medical school in The Journal of Felix Platter a medical student in Montpellier in the Sixteenth Century, trans. Seán Jennett (London: Frederick Muller Limited, 1962), 76. See also Bruce E. Hayes, "Putting the 'Haute' Back into the 'Haute Dame de Paris': The Politics and Performance of Rabelais' Radical Farce," French Forum 32.1 (2007): 39-52, and M. A. Screech, The Rabelaisian Marriage: Aspects of Rabelais' Religion, Ethics, and Comic Philosophy (London: Edward Arnold Publishers, Ltd., 1958), 139.

44. On the various uses of such terminology, see Alison Klairmont-Lingo, "The Fate of Popular Terms for Female Anatomy in the Age of Print," French Historical Studies 22.3 (1999): 335-49.

45. Dominique Brancher's article, "L’Anatomiste pornographe: Narration obscène et figuration de soi dans la literature médicale renaissante," gives a thorough and astute reading of Joubert's mention of anatomical demonstration in the context of the obscene implications of displaying nude bodies in early modern French anatomical demonstration. In Early Modern French Studies 14: Obscenity, 168-94. 
possible in order to fashion a more knowledgeable student, the physician must temper his language and his behaviour to adapt to the concerns and priorities of his patient. This ability to respond with decorum to the particular relationship with a patient, what we call bedside manner, was of paramount importance in the complex process of maintaining a professional distance that would assuage a patient's anxieties about the physician's intimate access to her or his body. ${ }^{46}$ As the Hippocratic treatise "On the Physician" states: "The intimacy also between physician and patient is close. Patients in fact put themselves in the hands of their physician, and at every moment he meets women, maidens, and possessions very precious indeed. So towards all these self-control must be used." ${ }^{47}$ In attempting to take on the role of physician through the medium of print, Joubert creates a situation in which it is impossible to respond to the particular concerns or anxieties of the individual patient. By addressing a wide audience of readers literate in the vernacular, Joubert inadvertently offends various members of this audience and risks jeopardizing his reputation as a practitioner of medicine as well as a theorist. The controversy surrounding the Erreurs Populaires and Joubert's response illustrates the difficulty that learned physicians faced as they crafted the authorial personas necessary for navigating the difficult relationship between professional information and contemporary concerns about decorum and propriety. For Joubert, this was an especially tricky balance to strike in a work that targeted an audience of women as potential patients even as it included material discussing topics relating to sex acts that some of Joubert's critics considered unacceptable for a genteel female readership.

\section{Conclusion}

The potentially titillating "sex acts" represented in these two vernacular medical works - the images from Estienne's anatomy and the inclusion of sexually explicit material in Joubert's Erreurs Populaires that provoked criticism and prompted Joubert and his printer to "warn" readers of obscene content-illustrate the

46. Cynthia Klestinec discusses the role of decorum in the new public anatomies, arguing that these demonstrations were not carnivalesque events as has sometimes been claimed. "Civility, Comportment, and the Anatomy Theatre: Girolamo Fabrici and His Medical Students in Renaissance Padua," Renaissance Quarterly 6.2 (2007): 434-63.

47. Hippocrates, “Physician,” trans. Paul Potter (Cambridge, MA: Harvard University Press, 1995), 303. 
possibility that early modern medical texts could generate controversy when addressing generation in the vernacular. Though medical writings had the primary purpose of teaching and aiding learned practitioners, the publication of Estienne's treatise with its clearly erotic images and the references to sex in Joubert raise important questions about the potentially illicit content of vernacular medical works of the sixteenth century. While physicians were interested in shoring up their institutional authority, they were also often committed to the print market as a way to further their reputations. Estienne and Joubert, as university-trained physicians, claimed a licit knowledge of sex that would, for example, help married couples to increase their fertility and produce a male heir. Yet this licit knowledge was sometimes presented in a way that seemed to aim at creating erotic pleasure for the unlearned practitioner and the non-professional reader. 


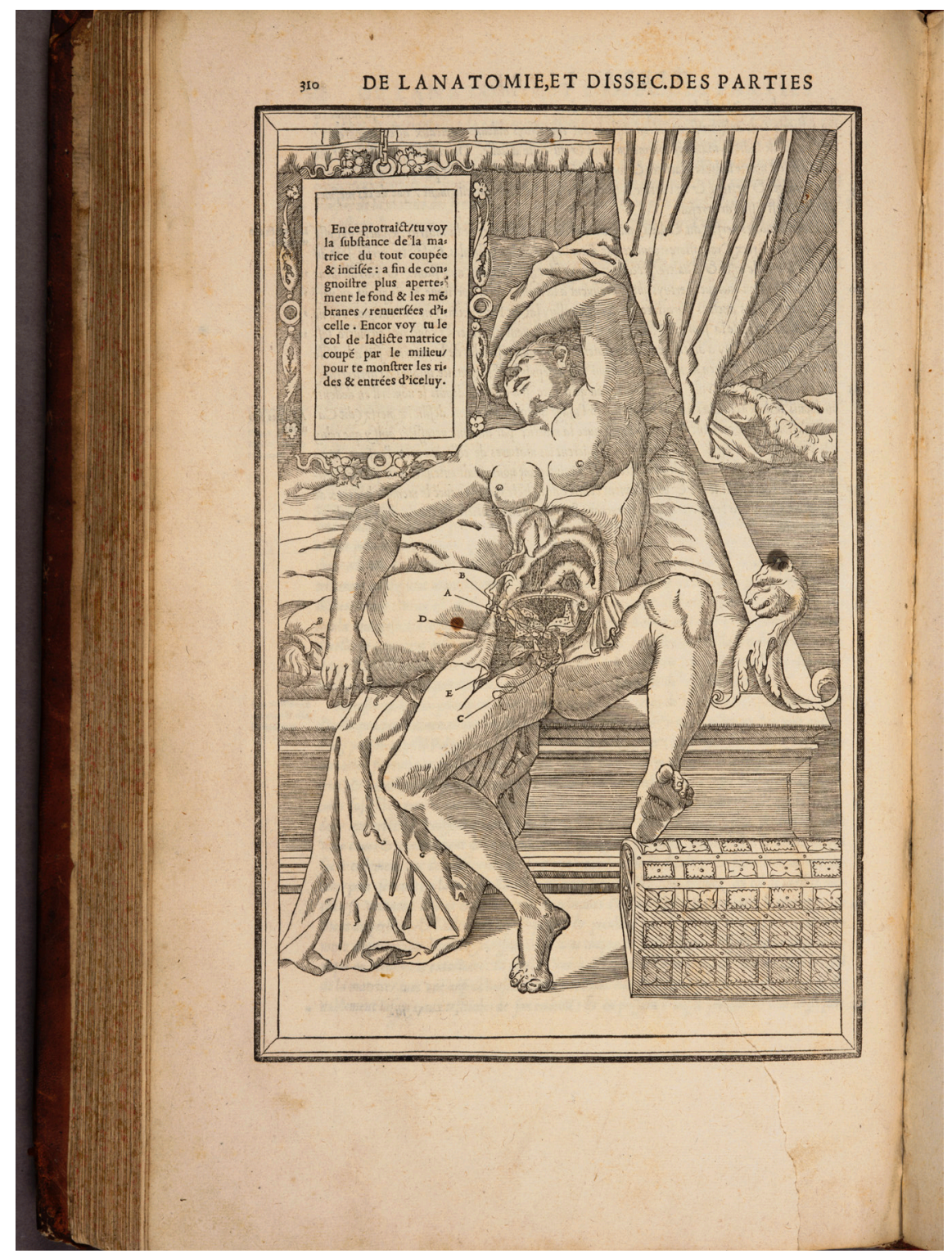

Figure 1. Charles Estienne, La dissection des parties du corps humain (Paris: Simon de Colines, 1546), p. 310, RB 621850, LACMA Collection, The Huntington Library, San Marino, California. 